\title{
EnVisaging a Future for Slavery: Agostino Brunias and the IMPERIAL Politics OF LABOR REPRODUCTION
}

\section{$\underline{\text { Sarah Thomas }}$}

The late eighteenth-century Caribbean paintings and prints of Anglo-Italian artist Agostino Brunias communicate a vision of contented and well-appointed slaves dancing, selling produce at market, leisurely washing clothes in luxuriant tropical landscapes, and dutifully attending to their "mulatto" mistresses. His idealized view of life in the Ceded Islands in the decades following the Seven Years' War satisfied the demands of British patrons whose careers, not to mention their fortunes, depended upon the profitability of slavery. By avoiding scenes of plantation labor, discipline, and punishment, and emphasizing instead the refinement, self-sufficiency, robust health, and fertility of slaves and free people of color, Brunias's imagery served to assuage mounting colonial anxieties concerning slavery's future. Ultimately, it communicated the imperial ideal of the kind of tropical arcadia that could result if planters treated their chattel slaves with a carefully calibrated measure of kindness and compassion. We shall see that Brunias's interest in flirting couples, epitomized by (but not limited to) his images of the bucolic dance, was a pictorial affirmation of this "benevolent" view of slave life. His images confirmed what many planters were asserting in their defense of slavery against mounting abolitionist dissent: that a humane slave society was not only possible, but sustainable too. 
From the 1770s onwards, a series of social reforms aimed at "ameliorating" slave conditions was gradually introduced across Britain's West Indian colonies. ${ }^{1}$ The rhetoric of amelioration stemmed from a broader Enlightenment ethic of benevolence, and coincided with the cult of Sensibility that valorized the "finer feelings." ${ }^{2}$ Some British slave reformers pointed to regulations in French and Spanish colonies, which they argued were less brutal in their treatment of the enslaved. ${ }^{3}$ One of their main objectives was to facilitate the natural increase of the Caribbean slave population, by-passing the slave trade altogether. By improving the health of local slaves and increasing the number of women on the plantations, so the case was often argued, the numbers of enslaved workers would expand naturally, and

\footnotetext{
${ }^{1}$ Hilary McD. Beckles, Centering Woman: Gender Discourses in Caribbean Slave Society (Kingston: Ian Randle Publishers, 1999), 159. While William Young and others were espousing the amelioration of slave conditions from the 1760 s onwards, it was not officially adopted as government policy for estate management until the 1790s. See J.R. Ward, British West Indian Slavery 1750-1834: The Process of Amelioration (Oxford: Clarendon Press,
} 1998), $2,7$.

${ }^{2}$ There is a substantial literature on slavery and the culture of Sensibility. See for example Karen Halttunen, "Humanitarianism and the Pornography of Pain in Anglo-American Culture," The American Historical Review 100, no. 2 (1995): 303-34; and Marcus Wood, Blind Memory: Visual Representations of Slavery in England and America 1780-1865 (Manchester: Manchester Univ. Press, 2000).

${ }^{3}$ Matthew Wyman-McCarthy, "Perceptions of French and Spanish Slave Law in Late Eighteenth-Century Britain,” Journal of British Studies 57 (2018). 
over time the African trade would become redundant. ${ }^{4}$ In Hilary Beckles' words, “managerial emphasis shifted slowly from 'buying' to 'breeding' as a labor supply strategy."

By the final decades of the century, amelioration was not only being advocated by planters but by leading abolitionists too. In a letter of 1788 , for instance, anti-slavery campaigner Granville Sharp wrote that the Committee for the Abolition of the Slave Trade had secured written evidence of several West Indian estates in which slave numbers had increased, "without any foreign supply, for many years ... a circumstance which affords the strongest proof ... that a proper attention to the principles of humanity in their treatment would preclude the necessity of any further supplied from the coasts of Africa. ${ }^{6}$ Pro-natalist sentiments were also being espoused by the West India lobby, including a group of eight Barbadian planters who opened their treatise, Instructions for the Management of a

\footnotetext{
${ }^{4}$ Ward, British West Indian Slavery, 2. See also David Brion Davis, The Problem of Slavery in an Age of Revolution, 1770-1823 (Ithaca: Cornell Univ. Press, 1975), 410-32.

${ }^{5}$ Beckles, Centering Woman, 159.

${ }^{6}$ Granville Sharp, letter from the London Committee for the Abolition of the Slave Trade, 15 January 1788. Published in Arthur Young (ed), Annals of Agriculture and Other Useful Arts (Bury St Edmonds, 1788), 85. This author's italics. A treatise advocating the gradual end to slavery by the Liverpool lawyer William Roscoe was also published the same year; among other reforms, he argued for the "propagation" of slaves. See Christa Dierksheide, Amelioration and Empire: Progress and Slavery in the Plantation Americas (Charlottes ville: Univ. of Virginia Press 2014), 160.
} 
Plantation (1786), with the words: "If negroes are fed plentifully, worked moderately, and treated kindly, they will increase in most places."7

The case for amelioration occupied a rare position of common ground between the opposing camps, one that is only recently receiving due attention from scholars. ${ }^{8}$ Planters believed that by "meliorating" the conditions of slavery they would be able maintain the status quo. For those who were disquieted by the horrors of slavery, on the other hand, amelioration policies seemed the most expedient way to improve the living conditions of those already enslaved. As historian Christa Dierksheide writes, "The two factions sought to realize their disparate goals of modernity through remarkably similar plans of "improvement." ${ }^{\text {"9 }}$ By the 1790 s, gradualist reform was being widely advocated across the political spectrum. ${ }^{10}$

Concurrent with the rising interest in amelioration was a developing capacity for quantifying enslaved populations: since the middle of the eighteenth century, more detailed, numerical accounts of increase and decreases in stock became standard practice on slave plantations. ${ }^{11}$ In the Barbadian plantation manual mentioned above, the author noted that,

\footnotetext{
${ }^{7}$ Edwin Lascelles et al, Instructions for the Management of a Plantation in Barbadoes and for the Treatment of Negroes (London: 1786), 22.
}

${ }^{8}$ See in particular Dierksheide, $\underline{\text { Amelioration and Empire; }}$ also George Boulukos, The Grateful Slave: The Emergence of Race in Eighteenth-Century British and American Culture (Cambridge: Cambridge Univ. Press, 2008), 10.

${ }^{9}$ Dierksheide, Amelioration and Empire, 2, 9.

${ }^{10}$ K. Paugh, "The Politics of Childbearing in the British Caribbean and the Atlantic World During the Age of Abolition, 1776-1838” Past \& Present 221 (2013): 2-4.

${ }^{11}$ Justin Roberts, Slavery and the Enlightenment in the British Atlantic, 1750-1807 (Cambridge: Cambridge Univ. Press, 2013), 59. 
"the increase [in slave numbers] is the only test of care with which they are treated." 12 In a 1791 speech to the House of Commons in support of his motion for abolition, William Wilberforce predicted that the end of the trade would "make breeding [enslaved AfroCaribbeans] the prime object of [planter] attention." 13 While abolition of the slave trade would not be won until 1807 (and emancipation not for a further twenty-six years), the latter decades of the eighteenth century witnessed a growing preoccupation with the "improvement" of slave conditions, and the fertility of the enslaved in particular.

This essay examines Brunias's oeuvre within this contested context, highlighting the artist's preoccupation with flirtatious couples, women with children and swollen bellies, multiple allusions to abundance, and slave autonomy. In sum, his work presents a visual compendium of a reformed slave society. It is no surprise to find that his key patron in the West Indies, Sir William Young (first baronet, 1724/5-1788), was an early advocate for treating enslaved Africans and their descendants with benevolence, a reformist view he first aired publicly over a decade before abolitionism's ascendancy. ${ }^{14}$ We shall see that Young

${ }^{12}$ Lascelles et al., Instructions for the Management of a Plantation in Barbadoes, 2. Cited by Roberts, Slavery and the Enlightenment in the British Atlantic, 60.

${ }^{13}$ The Parliamentary History of England, from the Earliest Period to the Year 1803: From Which Last-Mentioned Epoch It Is Continued Downwards in the Work Entitled Hansard's Parliamentary Debates, 36 vols. (New York: 1966), xxix, col 275. Cited in Paugh, "The Politics of Childbearing”, 119.

${ }^{14}$ See for example William Young, Considerations Which May Tend to Promote the $\underline{\text { Settlement of Our New West-India Colonies, by Encouraging Individuals to Embark in the }}$ Undertaking (London: James Robson, 1764). For another account of Young and Brunias 
believed adamantly that a planter's success was dependent upon compassion towards his slaves. The case for amelioration, and particularly the emphasis on pro-natalism, would later be developed by Young's son, also William Young (second baronet, 1749-1815), who by the end of the century had become one of Wilberforce's leading adversaries.

In the imagery of Brunias, life in the West Indies lacked any signs of brutality and coercion, and physical labor is rarely seen: there are no slave markets, with all their attendant violence and misery like those pictured in the 1820s by Augustus Earle, Jean Baptiste Debret, and other European artists living in Brazil. Brunias's enslaved subjects are not themselves for sale, but are rather autonomous vendors profiting from their exchanges in the market place. Yet as historians have long pointed out, the reality of slave life in the West Indies in the late eighteenth century was as cruel as it was enormously lucrative, for coerced labor demanded strict and often violent disciplinary measures on an unprecedented scale. Despite vigorous planter protestations to the contrary, extracting maximum profit often required instilling fear, and led readily to brutality and sadism. ${ }^{15}$ Stocks, treadmills, chain gangs, cages, iron masks and collars, workhouses, and jails were all visible reminders of the abuses that underpinned slave society. Brunias's imagery was a carefully contrived imperial fiction: in promoting the "amelioration" of slave conditions, it appeared to confirm the benefits of a humane slave society (real or imagined).

within the context of amelioration, see John E. Crowley, Imperial Landscapes: Britain's Global Visual Culture (New Haven: Yale Univ. Press), 2011, 126-32.

${ }^{15}$ B. W. Higman, A Concise History of the Caribbean (Cambridge: Cambridge Univ. Press, 2011), 143. 
Brunias had arrived in the West Indies in early 1765 at the invitation of Young, who had been appointed President of the Commission for the Sale of Lands in Dominica, Saint Vincent, Grenada and Tobago (ceded from France at the conclusion of the Seven Years' War). ${ }^{16}$ Young's official role involved promoting and overseeing the sale of land in the new islands to British investors, and with unabashed opportunism he wasted no time in also acquiring several estates for himself. By 1770 he was Governor of Dominica. While many of those who purchased land were speculators who never set foot on the islands, others were lured to settle. The Ceded Islands proved lucrative for the British. By 1773 they were already home to some 70,000 slaves, and their sugar exports met a fifth of the metropolitan demand: yields per slave were at least fifty percent higher than in the older West Indian colonies. ${ }^{17}$ Britain hoped to further develop and stabilize trade in the newly ceded territories by bolstering the British population in order to counter threats from both the French and the native Caribs. ${ }^{18}$ A profitable and sustainable slave system was key to this imperial vision.

${ }^{16}$ Amanda Bagneris questions the certainty of this date (ascribed by Lennox Honychurch), citing Edward Croft-Murray's mention of a 1766-7 decorative commission for William Chambers in London ("Decorative Painting in England, 1537-1837," Country Life, vol. 2, 1970, 177). Amanda Bagneris, Coloring the Caribbean: Agostino Brunias and the Painting of Race in the British West Indies, c.1765-1800, PhD, Harvard Univ., 2009, 32.

${ }^{17}$ Ward, British West Indian Slavery, 38, 96; Richard Sheridan, Sugar and Slavery: An Economic History of the West Indies (Kingston: Canoe Press, 2000), 452-9, 489-97. 18 Today, these people are known as the Kalinago. Patrick L. Baker, Centering the Periphery: Chaos, Order, and the Ethnohistory of Dominica (Montreal: McGill-Queen's Univ. Press, 1994), 62. 
Prior to his departure for the Caribbean, Italian-born Brunias had spent several years in Rome painting scenery and portraits for British visitors on the Grand Tour, before being employed as a draughtsman and decorative artist by the distinguished architect Robert Adam. Between 1754 and 1758 he worked in Adam's Rome studio, after which he relocated to London where he set to work painting friezes and decorative murals, and creating architectural designs for some of Adam's most noted stately homes. ${ }^{19}$ Of Brunias, Lennox Honychurch writes that he "would do in the Caribbean, what he had done for the English tourists in Rome; providing in paint, snapshots of their experiences and souvenirs of the places they had visited, in those days before photography." 20 Young was indeed quick to recognize the artist's talents and the potential of his experience with travelers on the Grand Tour. Yet what he would elicit from his artist were not, as we shall see, "snapshots" of the British West Indies, but rather examples of what W. J. T. Mitchell has evocatively termed the “"dreamwork' of imperialism." 21

${ }^{19}$ Lennox Honychurch, "Chatoyer's Artist: Agostino Brunias and the Depiction of St Vincent," Journal of the Barbados Museum and Historical Society 1 (2004): 124n1. The homes included Stowe, Osterly, Saltram, Audley End, Kedleston and Harewood. Guiliana Tomasella has recently uncovered further information regarding Brunias's work with Adam in England during this period. See Giuliana Tomasella, "Il Viaggio Come Scoperta Dell'alterità: Note Sul Pittore Agostino Brunias (1730-1796),” TeCLa 8 (2013): 13-19. See also Bagneris, Agostino Brunias: Capturing the Caribbean, 13-19.

${ }^{20}$ Honychurch, "Chatoyer's Artist".

${ }^{21}$ W. J. T. Mitchell, Landscape and Power (Chicago; London: Univ. of Chicago Press, 1994), 10. 
Brunias's role as Young's painter was to promote the Ceded Islands as a thriving colonial economy. His imagery conveyed an impression that slavery could be a highly cultivated affair, sending a "same but different" message to its European public, suggesting pictorially that slaves could (perhaps even should) be civilized by the apparent benefits of European dress and culture. The imagery confirms Kay Dian Kriz's notion of a "visual culture of refinement" that accompanied the brutal process of plantation slavery across the British West Indies. ${ }^{22}$ She justly points out that by completely ignoring the plantation system, and the islands' increasingly significant crop, sugar, the artist could envisage a harmonious society in which lavishly adorned slaves and free people of color engage in courtly dancing and elegant discourse. Kriz examines Brunias's fascination with "mulâtresses," whom he regularly-indeed repetitively_-portrayed parading their finery at Sunday markets. ${ }^{23} \mathrm{Her}$ detailed and well-considered analysis maps a racial, social, and gendered hierarchy of human types against the backdrop of Scottish Enlightenment thought. "Brunias's mulâtresses," she writes, "provoke the fantasy of possessing a body that both is and is not white, bearing the

${ }^{22}$ Kay Dian Kriz, Slavery, Sugar, and the Culture of Refinement: Picturing the British West Indies, 1700-1840 (New Haven, CT: Yale Univ. Press, 2008), 36-69.

${ }^{23}$ Slave-controlled markets, usually known as Sunday markets, were a highly significant social and economic institution in most slave societies, particularly in the West Indies. Provided with limited "free" time and provision grounds, slaves were permitted to grow produce for sale. 
marks of refined whiteness and the promise of savage sexual pleasure so closely associated with blackness." 24

Brunias was clearly fascinated by skin color as one marker of difference, alongside others, especially clothing. See, for example, Linen market, Dominica (c.1780) (Fig. 1), with its bustling port-side setting filled with a merry mélange of slaves, free people of color, and Caribs, all busily engaged together in trade. Sunday markets were run by slaves in their "free time," and provided an opportunity to sell homegrown provisions. The scene is one of diversity, social harmony, and opulence — an abundance of commodities (baskets overflowing with plump vegetables, crisp and decorated bolts of linen, and cut flowers) is clearly visible. Beth Tobin has noted astutely that such paintings posit a "hierarchy of beings" based primarily (although not solely) on racial difference. That a European artist visiting the Ceded Islands in the eighteenth century was struck by racial diversity is no surprise, with its rich mixture of Caribs, Africans, creoles, French, and British inhabitants. Brunias's works met a growing demand for such imagery that extended beyond his immediate patrons:

metropolitans in the period were increasingly curious about Britain's expanding empire, providing a ready market for pictures of diverse peoples. ${ }^{25}$

NOTE TO TYPESETTER: INSERT FIGURE \#1 HERE NOTE TO TYPESETTER: INSERT FIGURE \#2 HERE

${ }^{24}$ Kriz, Slavery, Sugar, and the Culture of Refinement, 45, 55. Kriz's choice of the term "mulâtresses" is accounted for by the fact that such women of mixed race in the early decades after the Seven Years' War were of French/African extraction.

${ }^{25}$ Christopher Brown, Moral Capital: Foundations of British Abolitionism (Chapel Hill: Univ. of North Carolina Press, 2012), 220. 
Racial diversity was a particularly visual subject, well suited to painters with their expanding array of available pigments: Market day, Roseau, Dominica, (c.1780) (Fig. 2) is a typical example of Brunias's careful attentions to skin colour. Such oils had no numbered codes aligning with written descriptions that could identify their taxonomic classification. The paintings distinguish individuals by skin color as well as by dress and occupation: the two "mulâtresses," for example, one standing and enjoying the avid attentions of a male suitor, the other seated, are distinguished both by their comparatively pale skin as well as their luxuriant dress. A black woman in the center of the background admires cloth, while others are seated in the painting's periphery. Despite their stratification of individual types however, Brunias's paintings are far more interested in the creation of socialized spaces rather than shallow stages for the typological indexing of humanity, as Tobin has argued. Brunias's concern was not with individuals, but with the constituency of slave society. He emphasizes this in his pressing concern with busy, populated spaces, in which his subjects engage in communal activities (trading, dancing, stick fighting): their dependence on each other is reinforced by each figure's purposeful (if strangely static) gaze in the direction of another, a succession of gazes that leads the viewer's eyes around the canvas.

For the most part, European figures in Brunias's oeuvre remain firmly offstage. ${ }^{26}$ In his scenes, the enslaved mingle freely and happily with people of color and indigenous Caribs; thriving social spaces are untroubled by the exigencies of imperial politics. There is no sign of white authority or surveillance on the one hand, or subaltern servitude on the other: there is only a naturalized harmonious society. While the artist provided a wealth of information about the clothing and customs of a wide spectrum of West Indian society, his

\footnotetext{
${ }^{26}$ There are some rare exceptions, including several works which include a sole European figure that some scholars have speculated may be a self portrait of the artist.
} 
larger purpose was not to provide a visual taxonomy for the benefit of Enlightenment science, but rather to envisage a civilized and prosperous imperial enterprise with a robust future.

By imbuing the enslaved with the restraint and politesse of the refined classes, Brunias's images diffused the fears of chaos and black savagery that were sending shivers of fear across the Atlantic. Planters in the Ceded Islands remained in genuine fear of resistance from the formidable Black Caribs of Saint Vincent and the maroons of Dominica right up until the 1790 s when they were subdued. ${ }^{27}$ In a radical departure from his usual subject matter, Brunias acknowledged such racial tensions, but transformed them into a peaceful and orderly encounter in which the British are clearly and calmly in control. Sir William Young conducting a treaty with the Black Caribs on the Island of Saint Vincent (c.1773) (Fig. 3), purports to document the moment in February 1773 when the Black Caribs gave up their war of resistance against the British in the face of annihilation or exile. ${ }^{28}$ In line with a profusion of British paintings and sculptures showing diplomatic encounters in various key places of empire, such as Robert Home's The reception of the Mysorean Hostage Princes by Marquis Cornwallis, 26 February 1792 (c.1793) (Fig. 4), Brunias's scene purports to record a diplomatic victory. While the surrendered weapons lying prominently on the ground imply a history of black violence (these are clearly not British guns), the British are armed with the

\footnotetext{
${ }^{27}$ Michael Craton, “Caribbean Region: British Caribbean,” in Seymour Drescher and Stanley L. Engerman, A Historical Guide to World Slavery (New York: Oxford Univ. Press, 1998), 131.
}

${ }^{28}$ Richard Gott, Britain's Empire: Resistance, Repression and Revolt (London: Verso, 2012), 3, 112 . 
accoutrements of imperial diplomacy: maps, written treaties, and the power of language (Young is obviously speaking, while his foe listens attentively). ${ }^{29}$

\section{NOTE TO TYPESETTER: INSERT FIGURE \#3 HERE NOTE TO TYPESETTER: INSERT FIGURE \#4 HERE}

Yet while he was clearly mindful of racial categorization (as Tobin, Kriz and more recently Amanda Bagneris have all pointed out), Brunias was most preoccupied with the health, happiness, and longevity of slave society. ${ }^{30}$ It is in his numerous images of the enslaved dancing that coupling and fecundity truly come to occupy center stage. Brunias was by no means the first artist to embrace the iconography of the slave dance: indeed, the subject had, at least since the seventeenth century, been somewhat of a trope, in literature as well as visual culture. Joseph Roach considers performance as a means by which diasporic communities invented themselves by "performing their pasts in the presence of others. They could not perform themselves, however, unless they also performed what and who they thought they were not." ${ }^{31}$ Roach invokes Homi Bhabha's well-known conception of colonial

${ }^{29}$ In 1801 the painting appeared in engraved form in Bryan Edwards' book The History, Civil and Commercial, of the British West Indies, under the title Pacification of the Maroon Negroes.

${ }^{30}$ Amanda Bagneris, Colouring the Caribbean: Race and the Art of Agostino Brunias (Manchester: Manchester Univ. Press, 2018).

${ }^{31}$ Joseph R. Roach, Cities of the Dead: Circum-Atlantic Performance, The Social Foundations of Aesthetic Forms (New York: Columbia Univ. Press, 1996), 5. Saidiya Hartman takes a different approach, viewing the iconography of dance as a cipher, not for a desired world of slave pleasure and prosperity, but rather for the profound anxieties and 
mimicry: "the desire for a reformed, recognizable Other, as a subject of difference that is almost the same, but not quite." 32 Roach's understanding of performance as an embodied form of memory in which the subject defines him or her self against an essential and in this case imperial Other, and Bhabha's notion of colonial mimicry, may thus provide clues to unlocking Brunias's dance imagery. After all, in such paintings as West Indian village with figures dancing (1770s) (Fig. 5), the enslaved appear to affect the kind of polite choreographed gestures of European dancers. Furthermore, they are adorned with accoutrements — lavish clothing, jewelry, a wig, even a fan-which, in the European context, would signify wealth and, by association, refinement. While the drum, a key signifier of African identity, is a ubiquitous feature in such images, here its warm tones virtually dissolve into the earthen background, in contrast to the brilliant whites of the refined linen and pearls, which jump out and catch the eye. Brunias's West Indian dancers can be understood as, in one sense, mimicking the cultured refinement of their wealthy European counterparts, "almost the same, but not quite."

\section{NOTE TO TYPESETTER: INSERT FIGURE \#5 HERE}

Here I wish to shift the focus from what these paintings might tell us about their enslaved subjects, to what light they shed on the imperial circumstances that bore them. Brunias clearly understood the requirements of his patrons (for he relied on patronage for a

inherent brutality of the imperial world, Scenes of Subjection: Terror, Slavery, and SelfMaking in Nineteenth-Century America (New York: Oxford Univ. Press, 1997), 7-8.

${ }^{32}$ Homi K. Bhabha, The Location of Culture (London: Routledge, 1994), 40. 
living), and he drew widely and selectively from what he witnessed in the Ceded Islands in order to fulfil a professional obligation. In his imagery, the slave dance came to offer planters hope that the trade in human beings could be dispensed with altogether if slaves could only live happily and procreate amongst themselves. West Indian village with figures dancing is a typical example of this halcyon vision, with its central group of polite dancing couples, its attentive drummer and tambourine player, and a sprinkling of young children (including a boy and girl showing obvious affection), all decorously arranged within a lush tropical setting. At first glance, such imagery appears to communicate the very essence of slave life through a set of highly ritualized tropical celebrations. Brunias' message is clear: here is a happy, healthy, and refined multi-racial society with ample provision, fine clothing, and individual autonomy. ${ }^{33}$

In this and other similar paintings Brunias visualizes his patron's benevolent views of slave management. These were clearly articulated in the months before Young departed for the West Indies in a fifty-page pamphlet, offering what was, in effect, an evangelizing manual for potential planters. Young's Considerations Which May Tend to Promote the

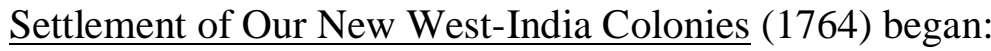

The desire of promoting an enterprise productive of both national advantage and private interest, has induced me to communicate to the publick such thoughts, as

\footnotetext{
${ }^{33}$ Only the unusual detail of the British-built fort in the background-possibly Fort Charlotte in St Vincent (personal communication with Mark Hauser, 8 June 2018)—belies the fact that the Ceded Islands were fiercely fought over in this period by French and British forces.
} 
may tend to advance the settlement of our new West India colonies, and encourage individuals to embark in so useful and lucrative an undertaking. ${ }^{34}$

The pamphlet provided a short introduction to the Islands and practical advice for the potential landholder, with sections on such matters as the choice of arable land, capital requirements, and the means of cultivating and maintaining estates. Young advocated a paternalistic approach to caring for one's labor force:

they should be well fed, properly cloathed [sic], and supplied with all those little aids of conveniency and comfort, which it is well known in that part of the world, will chear [sic] up and gladden their hearts. . . . As to the labour they must undergo, it should not be too severe, or disproportioned to their abilities . . . and in wet mornings, bad weather, and other suitable occasions, it will prove our interests to encourage, and afford them some indulgence. ${ }^{35}$

In short, Young argued that a planter's success relied on benevolence, and at its core was the physical and psychological health of his slave charges. He continued:

The miseries and misfortunes of our fellow creatures afford a melancholy contemplation to compassionate dispositions. How pleasing then must be the reflection, when the degrees of our private interest depend upon the measure of our

\footnotetext{
${ }^{34}$ Young, Considerations Which May Tend to Promote the Settlement of Our New WestIndia Colonies, 1.

35 Ibid., 47.
} 
benevolence. The first fair step of success will be to accompany humanity ... with the blessing of providence, to preserve the health of our people. ${ }^{36}$

Young's views were echoed elsewhere, such as in Antiguan planter Samuel Martin's Essay upon Plantership (1765), in which the author cautioned that a good planter should take care in deciding "what is the right or rational method of treating negroes, for rational beings they are, and ought to be treated accordingly; that is with humanity and benevolence, as our fellow creatures, created by the same Almighty hand." ${ }^{37}$ Ultimately such "benevolent" views were not driven by humanitarian motives as we might understand them today, but had selfinterest at their heart: namely, to ensure the long-term survival of slavery. "[I]t is conceived impossible," Young wrote, "to miscarry in other points [of establishing oneself as a planter], if we succeed in these [ameliorating slave conditions]." ${ }^{38}$ From an economic point of view, amelioration merely sought to shift the planter's source of profit from the importation of new African "stock" to investment in existing assets. ${ }^{39}$

\footnotetext{
${ }^{36}$ Ibid., 46.
}

${ }^{37}$ Samuel Martin, An Essay Upon Plantership, 4th ed. (London: Reprinted for A. Millar, 1765), 2.

${ }^{38}$ Young, Considerations Which May Tend to Promote the Settlement of Our New WestIndia Colonies, 48. Young's economic argument in favour of amelioration was again backed by Martin: "it is the interest of every planter to preserve his negroes in health and strength; so every act of cruelty is not less repugnant to the master's real profit, than it is contrary to the laws of humanity. .. good discipline is by no means inconsistent with humanity," An Essay Upon Plantership, ibid., 3.

${ }^{39}$ Beckles, Centering Woman, 159. 
Young senior returned to Britain in 1773, while Brunias remained in the West Indies for a further two years before returning to London where he continued to paint Caribbean scenes for absentee landholders, some of which he worked up into engravings. Five years later during the American War of Independence, Dominica was re-occupied by the French, followed by Saint Vincent. But after both islands were granted back to the British under the terms of the Treaty of Versailles in 1783, Brunias returned to Dominica to settle, remaining until his death in 1796. The fierce rivalry between the British and French as it played out in the Ceded Islands in these decades is alluded to in the artist's print, A cudgelling match between English and French negroes in the island of Dominica (1779) (Fig. 6). The print is far more portentous and highly choreographed than the related painting Cudgelling match (c.1780) (Fig. 7), with the former's heightened sense of dramatic tension and its more elaborate classical composition. The engraving was produced by Brunias as part of a series when he was living back in London. He dedicated it to Sir Ralph Payne, a Saint Kitts-born planter who several years earlier had been appointed governor of the Leeward islands (and was patron of the landscape artist Thomas Hearne). ${ }^{40}$ By the time Brunias inscribed his dedication, Payne was a parliamentarian and absentee landholder; the artist's dedication may well have been an attempt to win the favor of yet another planter patron.

${ }^{40}$ W. Courtney, "Payne, Ralph, Baron Lavington (1739-1807),” revised by Andrew J. O’Shaughnessy (Oxford: Oxford Univ. Press, 2004), online ed., January 2008, http://www.oxforddnb.com/view/article/21652. See also David Morris, Thomas Hearne and His Landscape (London: Reaktion, 1989). For further information about the dedicatees of Brunias's engravings, as well as a longer consideration of his representation of racial otherness, see David Bindman, "Representing Race in the Eighteenth-Century Caribbean: Brunias in Dominica and St Vincent, Eighteenth-Century Studies (2017) 51:1, 1-21. 


\section{NOTE TO TYPESETTER: INSERT FIGURE \#6 HERE}

\section{NOTE TO TYPESETTER: INSERT FIGURE \#7 HERE}

While the print's title consciously alludes to the Anglo-French rivalry that characterized the era, it is misleading, for of course we are not looking at a tussle between French and English citizens. Rather, these slaves were born either in Africa or the Caribbean, and their identification with each other (despite potential regional disparities) was likely to have been far stronger than that with their French or British masters. The notion of a "French" or "British" "negro" in this context denotes ownership rather than any sense of personal allegiance, and reminds us sharply of planters' proprietorial attitudes towards their slaves. Brunias makes no obvious pictorial distinction between his "French" and "English" fighters; such categories are created, rather, in the plate's inscription below the image. In the year following the print's production, Dominica and Saint Vincent were re-taken by the French; it would thus have seemed highly topical, witty perhaps, to symbolize the great rivalry of the two great European nations as a form of gentlemanly combat between colonial chattel. Payne would have appreciated the joke.

Given Young's views on the treatment of the enslaved, Brunias's images of dancing as a polite form of courtship take on an added significance. The engraving $\underline{\text { A negroes dance }}$ in the island of Dominica (1779) (Fig. 8) - a companion to A cudgelling match discussed above - is a typical example. It was produced as an individual plate and dedicated to the distinguished army officer Charles O’ Hara, Crown Surveyor (and landowner) in Dominica through the $1770 \mathrm{~s} .{ }^{41}$ In the center of the composition is a dancing couple, their eyes locked as

\footnotetext{
${ }^{41}$ Honychurch, "Chatoyer's Artist," 125n5. With regards to O’Hara’s land-holdings see John Byres, References to the Plan of the Island of Dominica, as Surveyed From the Year 1765 to 1773 (London: S. Hooper, 1779), 5.
} 
they engage in a courtly and demure ritual. The woman's belly and breasts are plump and alluring. Other figures congregate around them: two musicians, others conversing, and a young girl in the foreground. Behind the dancers stands a tree laden with coconuts. The bucolic tableau is one of untroubled merriment, social cohesion, and plenitude. More specifically, its focus upon the flirtatious engagement between the two central figures, the inclusion of a child, the dancer's swollen belly, and the prominence of a ripe fruiting tree are all powerful allusions to fertility. Women outnumber men by a ratio of two to one. The future of West Indian slavery — without the need for the African trade - appears secure.

\section{NOTE TO TYPESETTER: INSERT FIGURE \#8 HERE}

Young died in 1788, bequeathing to his son four sugar plantations, 896 slaves, and a debt of $£ 110,000$. Young junior inherited his father's views on amelioration, reporting to parliament decades later that on visiting the West Indies for the first time in 1771, he had already been "looking with an anxious eye to the condition of the negroes." 42 In the same hearing, the importance of "giving annual rewards to the women, in proportion to the number of their children" was noted. ${ }^{43}$ Shortly after the death of Young senior, the first of several amelioration acts was passed in Dominica, for the "encouragement, protection, and better government of slaves." It legislated among other points that every planter provide each of his

\footnotetext{
${ }^{42}$ William Young, Parliamentary Register, 6 April 1797, https://parlipapers-proquestcom.ezproxy.kingston.ac.uk/parlipapers/docview/t70.d75.pr_1796_1802000534? accountid=14557, 268 [accessed 22 August 2017].

${ }^{43}$ Charles Ellis, Parliamentary Register, 6 April 1797, https://parlipapers-proquestcom.ezproxy.kingston.ac.uk/parlipapers/docview/t70.d75.pr_1796_1802-
} 000534? accountid=14557, 237 [accessed 22 August 2017]. 
slaves with a proscribed quantity of clothing each year, and that an adequate house be built for every four or five slaves. ${ }^{44}$

By the time of Brunias's death, Young junior had become the leading parliamentary opponent of Wilberforce's abolitionist campaign. ${ }^{45}$ Amelioration, and in particular the natural rise of West Indian populations, was his rallying cry, and together with another planter he applied for approval from the West India Group of the House of Commons "to adopt such [ameliorationist] measures as would appear ... to obviate the Causes which have hitherto impeded the natural increase of the Negroes already in the islands. ${ }^{\circ 6}$ He tried to lead by

${ }^{44}$ Extract of a letter from Mr Chief Justice Ottley to Mr William Young, St. Vincent, 6 August 1788, https://parlipapers-proquestcom.ezproxy.kingston.ac.uk/parlipapers/result/pqpresultpage.gispdfhitspanel.pdflink/\$2fappbin $\$ 2$ fparliamentary-paper $\$ 2 f 6 \$ 2 f c \$ 2 f 2 \$ 2 f d \$ 2 f h c s p-001563 \_01-$ 487.pdf/treatment+slaves+William+young $\$ 40 \$ 2$ fapp-gis $\$ 2$ fparliamentary-paper $\$ 2$ fhcsp001563\$40Parliamentary+Paper\$40null\$40April+25,+1789?pg Id=9b5d4e06-a3e8-4ed0b3c6-9f3173a3a2b6\&rsId=15D6F521DEC [accessed 23 August 2017]; Lennox Honychurch, The Dominica Story: A History of the Island (London: Macmillan, 1995, 181).

${ }^{45}$ R.G. Thorne, The History of Parliament, entry for William Young, Second Baronet, http://www.historyofparliamentonline.org/volume/1790-1820/member/young-sir-william1749-1815 [accessed 5 September 2017].

${ }^{46}$ Charles Ellis, Parliamentary Register, 6 April 1797, https://parlipapers-proquestcom.ezproxy.kingston.ac.uk/parlipapers/docview/t70.d75.pr_1796_1802$\underline{000534}$ ?accountid $=14557,247$ [accessed 22 August 2017]. See also R.G. Thorne History of Parliament, http://www.historyofparliamentonline.org/volume/1790-1820/member/young-sirwilliam-1749-1815 [accessed 23 August 2017]. 
example, and on visiting one of his estates in St Vincent in 1791 described how he had given "such of the women as had reared their children ... as a present, five yards of fine cotton, at $2 s, 6 \mathrm{~d}$. per yard, of the gayest pattern, to make a petticoat," in an attempt to encourage them to bear him more laborers. ${ }^{47}$ Again the following year, when visiting his plantations on Tobago, he noted, "This last year I have had an increase of thirteen children, of whom only one has died. I ordered, as at St. Vincent's, five yards of fine printed cotton to every woman who had reared a child, and gave ten barrels of port among the negroes in general." 48

Brunias died in Dominica in 1796, but his works continued to circulate, particularly in printed form. Several of his engravings were incorporated into a seminal book written in response to abolitionist campaigning by another key member of the slave lobby, and advocate of amelioration, Bryan Edwards: The History, Civil and Commercial, of the British West Indies, which was widely distributed in both Britain and France. ${ }^{49}$ The first edition of 1793 was not illustrated, but a supplementary volume of maps and plates was produced the following year. The third edition, published in 1801, was embellished with engraved plates,

${ }^{47}$ Entry for 17 December 1791 in William Young, A Tour Through the Several Islands of Barbadoes, St. Vincent, Antigua, Tobago and Grenada, in the Years 1791, and 1792 (London: John Stockdale, 1801), 271.

${ }^{48}$ Entry for 17 March 1792 in Young, A Tour Through the Several Islands of Barbadoes, ..., 295.

${ }^{49}$ Bryan Edwards, The History, Civil and Commercial, of the British Colonies in the West Indies., 1st ed., 2 vols. (London: printed for John Stockdale, 1793): re-issued variously thereafter. 
several of which were after original paintings by Brunias from the private collection of Young junior. ${ }^{50}$ Brunias's engraving A negro festival, drawn from nature in the island of St. Vincent (1791) (Fig. 9) appeared in volume two of this edition. Again it focused on the subject of dancing: here are two couples, one black, one "mulatto," accompanied by a familiar seated drummer, a woman playing the tambourine, and a profusion of other less well-defined figures joining the party. A hawker (one of Brunias's stock figures) arranges her goods in the foreground - the fruiting tree from the earlier A negroes dance has here been transformed into a plentiful array of fruit and vegetables, symbols again of abundance and fertility.

\section{NOTE TO TYPESETTER: INSERT FIGURE \#9}

The plate was inserted at the end of Edwards' impassioned argument in favor of "ameliorating" slave conditions. ${ }^{51}$ Here, Edwards noted positive changes to slave societies (particularly those in Jamaica, Grenada, and Dominica), where the enslaved were now "entitled to a protection that in former times would have been thought incompatible with the dependence and insubordination of slavery". ${ }^{52}$ Most abolitionists, he asserted, viewed amelioration as merely the first step toward a:

${ }^{50}$ List of Maps and Plates for Bryan Edwards, History, Civil and Commercial, of the British Colonies in the West Indies: In Two Volumes (London, 1794). Brunias's engravings were published in the editions of 1801, 1807 and 1818-1819.

${ }^{51}$ Bryan Edwards, The History, Civil and Commercial, of the British Colonies in the West Indies., $3^{\text {rd }}$ ed., vol. 2. (London: John Stockdale, 1801), opp. 186.

${ }^{52}$ Ibid., 168. 
more extended and liberal plan ... by stopping the further influx of Negroes into our islands, to compel the planters to cherish and husband their present stock; and sustain it in future by natural encrease [sic]; until, by milder treatment, and the Christian institutes, the manners of the slaves shall become softened, their vices corrected, and their dispositions gradually prepared for a total emancipation. . . ${ }^{53}$

Edwards viewed the institution of slavery as an inherently dynamic process, one that not only strengthened the imperial bonds between Britain and the West Indies, but was also a great civilizing force.${ }^{54}$ For him the problems were various, but foremost among them was a general lack of enslaved women, and the practice of polygamy (which in his view led to promiscuity among women, and thence to "barrenness, frequent abortions ... and want of maternal affection towards their children)." ${ }^{\prime 55}$ A negro festival is typical of Brunias's oeuvre in visualizing exactly the form of slave society being advocated by Edwards and his planter predecessors. Here again women clearly outnumber men, while widespread anxieties around miscegenation are neatly avoided in the distinct pairing of "mulatto" and black couples.

In such images, Brunias could offer a vision of a unified, happy, and sustainable slave society, one which could subtly remind his viewers of the source of the empire's wealth, but also assuage mounting anxieties as the eighteenth century wore on. In the decade that Young senior and Brunias had first encountered the West Indies, the diminishing authority of Britain over its North American colonies was already causing concern, and the eventual loss of those

${ }^{53}$ Ibid., 178 (this author's italics).

${ }^{54}$ Dierksheide, Amelioration and Empire, 157.

${ }^{55}$ Edwards, The History, Civil and Commercial, 176. 
colonies in 1783 was for Britain a very real trauma. Old certainties around the relationship of colonies and colonists to the metropole were being questioned, and negotiations were taking place about how the colonies should be ruled, administered, defended, and financed. ${ }^{56}$ In short, the imperial project itself was being interrogated. No wonder then that pictures by an authoritative artist — one who had witnessed plantation slaves with his own eyes—which appeared to confirm the viability, sustainability, and profitability of slavery in Britain's newest West Indian colonies, were deeply reassuring. Brunias's vision of a tropical Eden, ordered and contained by a rigid racial and social hierarchy, bears no marks of imperial intrusion or dependence: slaves, native Caribs, and free people of color are the artist's primary subjects, while (with rare exceptions) white planters and all material evidence of them are barely visible.

Driven by the demands of imperial patrons, Brunias's output assured viewers not only that a slave society could attain a level of cultivation but that, ultimately, it could be selfsustaining. While the imagery gave visual form to the ameliorationist arguments being made by both abolitionists and the pro-slavery lobby alike, provenance research suggests that the artist's key audience was predominantly the latter. Certainly his prints from the late 1770s while in London were dedicated (from an "Obliged and dedicated servant") either to his patron or to a range of sympathetic politicians and colonial administrators with West Indian interests. ${ }^{57}$ That Brunias's images served the planter class is not surprising, given their

\footnotetext{
${ }^{56}$ Brown, Moral Capital, 239.

${ }^{57}$ These include: John George Felton (Inspector-General of His Majesty's Customs of the Leeward Islands); Patrick Blake of Montserrat (First Bart, and MP for Sudbury), John Frederick (Commissioner of Customs), Charles O'Hara (Brigadier General of his Majesty's
} 
idealized visions of an apparently harmonious mixed-race society, very little evidence of surveillance or imperial authority, and no whiff whatsoever of the society's coercive and brutal underpinnings. What is perhaps more surprising is that Brunias's refined and congenial enslaved subjects spoke not only to the struggling planter, but also, subsequently, to an AfroCaribbean population curious to "see" its own history and keen to identify with Brunias's contented subjects. Most striking is the example of a series of eighteen buttons (Fig. 10) featuring painted scenes of slave life derived from Brunias, which were reputedly (perhaps erroneously) said to have adorned the jacket of the heroic slave leader of the Haitian Revolution, Toussaint L'Ouverture. Whether or not the story is apocryphal, the idea that the imagery may have been co-opted thus by the black revolutionary is plausible. ${ }^{58}$

\section{NOTE TO TYPESETTER: INSERT FIGURE \#10}

The artist's works circulated both in Europe and throughout the West Indies as engraved plates in books and as individual paintings and prints. They served a multitude of purposes simultaneously: sanitized aide-mémoires for absentee planters and colonial administrators, pleasing reassurance for the pro-slavery lobby, and enticement to potential investors. What they purported to confirm was that amelioration was both an achievable and effective imperial policy, one that could safeguard the future of slavery in the face of rising abolitionist dissent. Ultimately, the argument was lost when Britain formally emancipated its slaves in 1833 . Yet the images continued to circulate freely across the Caribbean, and remain relevant for other reasons today. We can only appreciate their impact in the latter half of the

\footnotetext{
Army in America and Crown Surveyor in Dominica); and Ralph Payne (politician and Governor-in-Chief of the Leeward Islands).

${ }^{58}$ Bagneris, Coloring the Caribbean, 158-59.
} 
eighteenth century, however, if we are able to retrieve some of the complexities and a sense of the urgency of abolitionist and pro-slavery politics in the period. The Ceded Islands, intensely fought over by the empires of Britain and France in the decades following the Seven Years' War, were the site of bitter struggles and profound colonial fears; for the enslaved themselves, the islands witnessed unimaginable violence and hardship. Such narratives remain hidden behind the idealized tableaux of Brunias, yet by steeping the imagery within the broader imperial archive, we can start to recover some of the uncomfortable histories that shaped the period. 